\title{
Development Of Student Worksheet Based on Inquiry in Carbohydrate Metabolism Material to Increase Study Results of 2015 Biology Education Student
}

\author{
Sari Kusuma Dewi ${ }^{1}$, Yuliani ${ }^{2}$, Yuni Sri Rahayu ${ }^{3}$ \\ Department of Biology \\ Universitas Negeri Surabaya \\ Surabaya, Indonesia \\ ${ }^{1}$ saridewi@unesa.ac.id, 22yuliani@unesa.ac.id, 3yunirahayu@unesa.ac.id
}

\begin{abstract}
The purpose of this research was produce carbohydrate metabolism student worksheet based on valid and effective inquiry. Validity of student worksheet was gained by validation sheet instrument, and the effectiveness was obtained from study result completeness and student's response to student worksheet. Student worksheet developed on this research included topic of photosynthesis and respiration. This study was development research, and trialed on 2015 biology education student. The data were analyzed by quantitative descriptive. This result showed student worksheet was valid which reviewed from feasibility of presentation, material, content with score average 3,75. Uses of student worksheet on effective study process was obtained from study results of 2015 biology education student which showed average value 70,02 for photosynthesis subject and 65,97 for respiration subject. Student's response to student worksheet were positive up to $90,32 \%$, they assumed this carbohydrate metabolism student worksheet were effective.
\end{abstract}

Keywords-inquiry based student worksheet; carbohydrate metabolis; study results.

\section{INTRODUCTION}

Plant physiology subject maintains some basic concepts that have to learn by student since they apply basic biology subject on first semester, as example concept about enzyme mechanism, light reaction process, dark reaction and respiration mechanism. This subject must be programmed and passed completely with good value.

Hence the study results which showed by biology education student on mid-semester exam included of metabolism (enzyme, photosynthesis, respiration, ammonium metabolism and fat metabolism) were low grade. As a representation for study results of 2014 biology education student value at range $32-71.75$ with average value 57. This low average value in plant metabolism was caused by decreasing value in carbohydrate metabolism (photosynthesis and respiration), which respectively average value for photosynthesis subject was 62.32 and respiration subject was 51. Low student study results indicate that student having difficulty in carbohydrate metabolism learning.
Based on that background, carbohydrate metabolism student worksheet based on inquiry developed in this research. Inquiry based student worksheet was expect to help student build their own understanding about natural concept by surrounding. Therefore student study results can increase with find by itself subject concept that have been learning. As defined by the researcher about inquiry, inquiry was an instructional approachment that includes students did scientific inquiries which focus on creation, evaluation and scientific model revision that applied to understand and predict nature [1]. Another inquiry view [2] was a process to find new casual relation, where students state a hypothesis and try them through by observation or experiment. Based on definition, inquiry was learning strategies which invite student for solving problem through experimental activity in case student can build their own understanding which started from formulate a solution, obtain data in experiment and make conclusion.

Student worksheet is one of teaching materials which is needed in learning process, which aims to ease the lecturer in learning and as a learning resources alternative for student. As one of teaching materials, student worksheet used in learning has to fulfill the teaching materials feasible criteria. Furthermore student worksheet which developed has function to increase student's process skill. There are three sub-skill which form critical thinking skills was analyze, evaluation and inferention [3]. Student worksheet which developed on this research was designed to fulfill the three sub-skill, related to increases student study results.

The purpose of research was produce carbohydrate metabolism student worksheet based on valid and effective inquiry. Validity of student worksheet was gained by validation sheet instrument, and the effectiveness was obtained from study result completeness and student's response against student worksheet. This result usefully as a lecturer's reference in order to increase student study result by practicing process skill, another function this carbohydrate metabolism student worksheet applicable by lecturer or student that has been through revision and trial test. 


\section{METHODS}

This study was development research of student worksheet based on inquiry with carbohydrate metabolism subject (photosynthesis and respiration), trialed on 2015 biology education class as 30 students, using one group pretest and post test design. Student worksheet validated by content and educations professional, include feasibility of presentation, content, language and inquiry component. Student worksheet was valid based on validation result if average value $\geq 2.8$. Meanwhile the carbohydrate metabolism student worksheet effectiveness obtained from study result completeness through test method, which pretest and post test using inquiry student worksheet. The study worksheet's subject which is given was carbohydrate metabolism include photosynthesis and respiration (2 topics). Student study result determined complete if cognitive value test student fulfill the criteria set by Department of Biology Universitas Negeri Surabaya $\geq 65$ (B-). The other effectiveness gained from student's response through questionnaire method. Student study result determined effective if positive response percentage given by student $\geq$ $71 \%$. The data were analyzed statistically by quantitative descriptive.

\section{RESULTS AND DISCUSSION}

\section{A. Results}

\section{a). Validity of Carbohydrate Metabolism Student Worksheet}

The validations result against carbohydrate metabolism student worksheet which obtained from two lecturers was explained on Table 1.

TABLE I. AVERAGE VALIDATIONS RESUlT AGAINST CARBOHYDRATE METABOLISM STUDENT WORKSHEET

\begin{tabular}{|c|c|c|c|}
\hline $\begin{array}{l}\text { Table } \\
\text { Head }\end{array}$ & Valuation Aspect & $\begin{array}{c}\text { Validator } \\
1\end{array}$ & $\begin{array}{c}\text { Validator } \\
2 \\
\end{array}$ \\
\hline \multicolumn{4}{|c|}{ A. Legibility } \\
\hline 1 & Using correctly spelling & $4^{\mathrm{a}}$ & $3^{b}$ \\
\hline 2 & $\begin{array}{l}\text { Type of font and font size } \\
\text { which used to ease of reading }\end{array}$ & 4 & 4 \\
\hline \multirow[t]{2}{*}{3} & $\begin{array}{l}\text { Language that used in student } \\
\text { worksheet is not having } \\
\text { difficulty to understanding }\end{array}$ & 4 & 4 \\
\hline & Average of Legibility & \multicolumn{2}{|l|}{3,83} \\
\hline \multicolumn{4}{|c|}{ B. Content } \\
\hline 5 & $\begin{array}{l}\text { The content delivered accord } \\
\text { to concept }\end{array}$ & 4 & 4 \\
\hline 6 & $\begin{array}{l}\text { The content accord to } \\
\text { learning goals }\end{array}$ & 4 & 4 \\
\hline 7 & $\begin{array}{l}\text { Problems orientation make } \\
\text { student probably to formulate } \\
\text { a problem }\end{array}$ & 4 & 3 \\
\hline 8 & $\begin{array}{l}\text { This student worksheet } \\
\text { practices student on } \\
\text { Integrated Process Skill in } \\
\text { order to } \\
\text { - formulate a problem, } \\
\text { - make hypothesis, } \\
\text { - variable identification, } \\
\text { - trial design }\end{array}$ & 4 & 4 \\
\hline
\end{tabular}

\begin{tabular}{|c|c|c|c|}
\hline $\begin{array}{l}\text { Table } \\
\text { Head }\end{array}$ & Valuation Aspect & $\begin{array}{c}\text { Validator } \\
1\end{array}$ & $\begin{array}{c}\text { Validator } \\
2\end{array}$ \\
\hline & $\begin{array}{l}\text { - arrange procedure of study } \\
\text { - experimentalize } \\
\text { - present data in table } \\
\text { - analyze data } \\
\text { - make conclusion } \\
\text { expand the concept }\end{array}$ & & \\
\hline 9 & $\begin{array}{l}\text { Student worksheet can extend } \\
\text { insight about photosynthesis } \\
\text { and its application }\end{array}$ & 4 & 4 \\
\hline 10 & $\begin{array}{l}\text { Student worksheet can extend } \\
\text { insight about respiration and } \\
\text { its application }\end{array}$ & 4 & 4 \\
\hline 11 & $\begin{array}{l}\text { Time allocation in student } \\
\text { worksheet is enough for } \\
\text { activity on student worksheet }\end{array}$ & 3 & 3 \\
\hline 12 & $\begin{array}{l}\text { Method in student worksheet } \\
\text { is coherent and clear }\end{array}$ & 4 & 4 \\
\hline 13 & $\begin{array}{l}\text { Instruction in this student } \\
\text { worksheet easily to } \\
\text { understand and clear }\end{array}$ & 4 & 4 \\
\hline 14 & $\begin{array}{l}\text { Questions, discussion and } \\
\text { concept expandness in student } \\
\text { worksheet raise student's } \\
\text { curiosity }\end{array}$ & 3 & 4 \\
\hline 15 & $\begin{array}{l}\text { This student worksheet make } \\
\text { student more active in } \\
\text { learning }\end{array}$ & 4 & 4 \\
\hline & Average of Content & \multicolumn{2}{|l|}{3.82} \\
\hline \multicolumn{4}{|c|}{ C. Content } \\
\hline 16 & $\begin{array}{l}\text { Compatibility topic on } \\
\text { student worksheet with } \\
\text { subject }\end{array}$ & 4 & 4 \\
\hline 17 & $\begin{array}{l}\text { Represent learning goals } \\
\text { which will achieved }\end{array}$ & 4 & 3 \\
\hline 18 & $\begin{array}{l}\text { Represent tools and materials } \\
\text { on student worksheet }\end{array}$ & 4 & 4 \\
\hline 19 & $\begin{array}{l}\text { Compatibility cover with } \\
\text { topic }\end{array}$ & 4 & 3 \\
\hline \multirow[t]{3}{*}{20} & $\begin{array}{l}\text { Compatibility layout with } \\
\text { picture }\end{array}$ & 3 & 3 \\
\hline & Average of Presentation & 3.6 & \\
\hline & $\begin{array}{l}\text { Average of student worksheet } \\
\text { validations result }\end{array}$ & \multicolumn{2}{|l|}{3.75} \\
\hline
\end{tabular}

The validations result on student worksheet showed score 3.75 with very valid criteria and feasible to apply. From valuation aspect which is showed the highest score was content aspect (3.82) followed by legibility aspect (3.83) and presentation aspect (3.6). Student worksheet stated by validator maintains component of integrated process skill. Validator gave advice for student worksheet's revision as explained on Table II.

TABLE II. VALIDATOR'S ADVICE RELATED TO STUDENT WORKSHEET

\begin{tabular}{|l|l|}
\hline Number & \multicolumn{1}{|c|}{ Student Worksheet Revision Advice } \\
\hline 1 & Numbering arrangement so that more communicative \\
\hline 2 & $\begin{array}{l}\text { Revision on picture explanation in respirations student } \\
\text { worksheet can't reading easily }\end{array}$ \\
\hline
\end{tabular}




\begin{tabular}{|l|l|}
\hline Number & \multicolumn{1}{|c|}{ Student Worksheet Revision Advice } \\
\hline 3 & Added goals related to the concept to be built \\
\hline 4 & Added writer's name \\
\hline
\end{tabular}

b). Student's Study Result

This results showed there was increase of student study result up to $33.84 \%$ for photosynthesis subject and $28.84 \%$ for respiration subject as examined on Table 2.

TABLE III. Cognitive Study Result of Biology Students

\begin{tabular}{|c|c|c|c|c|}
\hline \multirow{2}{*}{$\begin{array}{c}\text { Num } \\
\text { ber }\end{array}$} & \multicolumn{2}{|c|}{ Pretest } & \multicolumn{2}{|c|}{ Post test } \\
\hline & Photosynthesis & Respiration & Photosynthesis & Respiration \\
\hline 1 & 40 & 41 & 60 & 65 \\
\hline 2 & 32 & 57 & 71 & 77 \\
\hline 3 & 40 & 39 & 70 & 65 \\
\hline 4 & 40 & 33 & 75 & 78 \\
\hline 5 & 20 & 28 & 55 & 55 \\
\hline 6 & 52 & 40 & 62 & 80 \\
\hline 7 & 27 & 46 & 60 & 73 \\
\hline 8 & 21 & 13 & 82 & 60 \\
\hline 9 & 40 & 28 & 56 & 50 \\
\hline 10 & 37 & 41 & 65 & 80 \\
\hline 11 & 41 & 52 & 69 & 80 \\
\hline 12 & 43 & 46 & 68 & 55 \\
\hline 13 & 57 & 45 & 55 & 90 \\
\hline 14 & 31 & 53 & 95 & 99 \\
\hline 15 & 38 & 40 & 65 & 60 \\
\hline 16 & 43 & 33 & 55 & 55 \\
\hline 17 & 35 & 32 & 60 & 65 \\
\hline 18 & 22 & 37 & 65 & 69 \\
\hline 19 & 20 & 19 & 67 & 65 \\
\hline 20 & 38 & 12 & 60 & 50 \\
\hline 21 & 43 & 14 & 82 & 68 \\
\hline 22 & 22 & 39 & 60 & 55 \\
\hline 23 & 40 & 32 & 60 & 50 \\
\hline 24 & 31 & 44 & 93 & 71 \\
\hline 25 & 43 & 36 & 72 & 71 \\
\hline 26 & 31 & 43 & 79 & 75 \\
\hline 27 & 43 & 37 & 66 & 72 \\
\hline 28 & 36 & 36 & 83 & 72 \\
\hline 29 & 40 & 35 & 58 & 50 \\
\hline 30 & 45 & 10 & 82 & 50 \\
\hline
\end{tabular}

\begin{tabular}{|l|r|r|r|r|}
\hline Num & \multicolumn{2}{|c|}{ Pretest } & \multicolumn{2}{|c|}{ Post test } \\
\hline $\mathbf{3 1}$ & 46 & 25 & 89 & 72 \\
\hline $\mathbf{3 2}$ & 37 & 54 & 65 & 65 \\
\hline $\mathbf{3 3}$ & 37 & 35 & 97 & 70 \\
\hline $\mathbf{3 4}$ & 27 & 44 & 60 & 50 \\
\hline $\mathbf{3 5}$ & 33 & 31 & 65 & 50 \\
\hline $\mathbf{3 6}$ & 31 & 42 & 95 & 68 \\
\hline $\mathbf{3 7}$ & 32 & 35 & 70 & 69 \\
\hline $\mathbf{3 8}$ & 41 & 22 & 70 & 65 \\
\hline & $\mathbf{1 3 7 5}$ & $\mathbf{1 3 9 6}$ & $\mathbf{2 6 6 1}$ & $\mathbf{2 5 0 7}$ \\
\hline & $\mathbf{3 6 . 1 8}$ & $\mathbf{3 5 . 5 0}$ & $\mathbf{7 0 . 0 3}$ & $\mathbf{6 6 . 1 6}$ \\
\hline
\end{tabular}

\section{THE AVERAGE OF STUDENT'S STUDY RESULT}

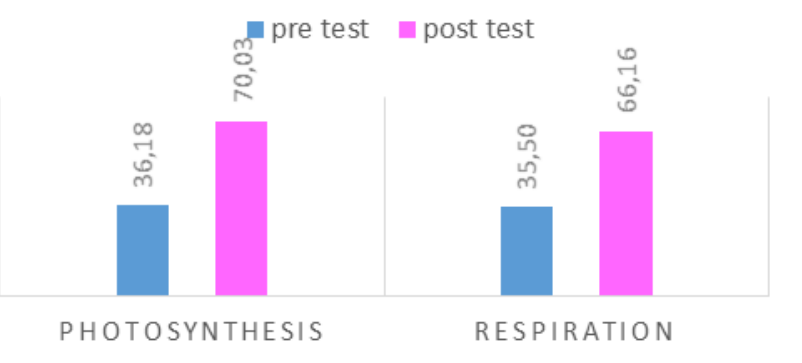

Fig. 1. Graph of cognitive study result of biology students average

Study result of 2015 biology education students showed value average B (70.03) for photosynthesis subject and B(66.16) for respiration subject. On photosynthesis subject, 25 from 38 students gained $B$ - value $(\geq 65)$ which was up to $65.78 \%$ included of good and effective category at range of value 55-97. For study results on respiration subject as 23 students gained B- value, up to $60.52 \%$ with good and effective category. Range of value on respiration subject was 50-99. Although the increase from pretest going to posttest up to $28.84-33.84 \%$ but the earned value still at good category.

c). Student's Response to Carbohydrate Metabolism Student

Worksheet.

Student's response result to application of carbohydrate metabolism student worksheets based on inquiry can be explained on Table IV.

TABLE IV. STUDENT'S RESPONSE AGAINST CARBOHYDRATE METABOLISM STUDENT WORKSHEET

\begin{tabular}{|c|l|c|}
\hline Number & \multicolumn{1}{|c|}{ Aspect of Value } & $\begin{array}{c}\text { Percentage } \\
(\%)\end{array}$ \\
\hline \multicolumn{2}{|l|}{ A. Legibility } & 96,77 \\
\hline 1 & $\begin{array}{l}\text { Did the type of font and font size which } \\
\text { used to ease of reading this student }\end{array}$ & 9 \\
\hline
\end{tabular}




\begin{tabular}{|c|c|c|}
\hline Number & Aspect of Value & $\begin{array}{c}\text { Percentage } \\
(\%)\end{array}$ \\
\hline & worksheet? & \\
\hline 2 & $\begin{array}{l}\text { Did the language in this student worksheet } \\
\text { is not having difficulty to understanding? }\end{array}$ & 96,77 \\
\hline \multicolumn{3}{|c|}{ B. Content } \\
\hline 3 & $\begin{array}{l}\text { Did this student worksheet practice you in } \\
\text { order to : } \\
\text { - formulate a problem, } \\
\text { - make hypothesis, } \\
\text { - variable identification, } \\
\text { - trial design } \\
\text { - arrange procedure of study } \\
\text { - experimentalize } \\
\text { - present data in table } \\
\text { - analyze data, } \\
\text { - make conclusion }\end{array}$ & 100 \\
\hline 4 & $\begin{array}{l}\text { Did this student worksheet extend your } \\
\text { insight about photosynthesis subject and } \\
\text { its application? }\end{array}$ & 96,77 \\
\hline 5 & $\begin{array}{l}\text { Did this student worksheet help you to } \\
\text { understand respiration subject and its } \\
\text { application? }\end{array}$ & 96,77 \\
\hline 6 & $\begin{array}{l}\text { Did this time allocation in student } \\
\text { worksheet is enough for activity on } \\
\text { student worksheet? }\end{array}$ & 51,61 \\
\hline 7 & $\begin{array}{l}\text { Did method in this student worksheet is } \\
\text { coherent and clear? }\end{array}$ & 96,77 \\
\hline 8 & $\begin{array}{l}\text { Did the instruction in this student } \\
\text { worksheet easily to understand and clear? }\end{array}$ & 90,32 \\
\hline 9 & $\begin{array}{l}\text { Did the questions, discussion and concept } \\
\text { expandness in student worksheet raise } \\
\text { your curiosity? }\end{array}$ & 90,32 \\
\hline 10 & $\begin{array}{l}\text { Did this student worksheet make you more } \\
\text { active in learning? }\end{array}$ & 93,55 \\
\hline \multicolumn{3}{|c|}{ C. Presentation } \\
\hline \multirow[t]{2}{*}{11} & $\begin{array}{l}\text { Did this student worksheet's presentation } \\
\text { is attractive? }\end{array}$ & 83,87 \\
\hline & Average of Percentage Total & $\mathbf{9 0 , 3 2}$ \\
\hline
\end{tabular}

Student's response to carbohydrate metabolism student worksheet was positive up to $90.32 \%$ with very good criteria. Students consider that application of student worksheet could train students to formulate a problem, make hypothesis, trial design, make observation, analyze data and make conclusion. Student worksheet helps to understand subject of photosynthesis and respiration, so that increase student's study result.

\section{B. Discussion}

The result of this research was valid metabolism student worksheet based on inquiry and aim to increase the study result of students. The student worksheet based on inquiry was valid by didactic requirements which was involving student to be active in learning activity, emphasizing student to found the concept, developing student to increase their communication skill, and the experience of study which was increased by their experience theirselves through student worksheet based on inquiry. Beside that, there was a construction requirements including language use, vocabulary, level of difficulty, and clarity of sentences., and the last was a technic requirements which was emphasize student worksheet including writing, picture, and appearance [4]

Learning activity which implement student worksheet based on inquiry aims to make students discuss to design inquiries activity against presented problem according to process that has been determined, also in order to train communication skill of student and process their emotion in discussion activity. With a group discussion which design inquiries activity against presented problem in inquiry student worksheet and thus student worksheet invite student be an active in learning activity, so according to main function of student worksheet which is to be one of teaching materials that optimizes learning pattern centered on student [5]. This thing was supported by student's response against student worksheet which state application of student worksheet to train student in order to formulate a problem, make hypothesis, trial design, make observation, analyze data and make conclusion [6].

The carbohydrate metabolism material including photosynthesis and respiration was abstract and difficult material, so the student need to explore their skills to associate one to another concepts. Even though their respiration study result did not get B score but it about had been increased $28.84 \%$.

The use of inquiry student worksheet on metabolism material could increase the student study result, because of the initial treatment, the student had been given a metabolism phenomenal case. The learning process had been done by investigated, problem solved, and observed would involve to higher thinking skill and student study result, those learning process would be more meaningful to student because their active involvement in learning process [7].

This result showed that most of them get used to and mastered all stages from skill process because student get used to think abstract with get used to doing science process skill stages. Based on theory of cognitive development Piaget, child on 11 years up included of formal operational stage [8], which has skill to think abstract, think logically and make conclusion from any available information. This thing was supported by previous study [9] which explained by doing inquiry based learning can increase student's skill, another research [10] conclude that inquiry learning model can increase science process skill.

Inquiry learning model also to expand student's insight and to practice students process skill. Student worksheet with good development will increase student's interest into learning process, so that help student to master the subject easily and to train process skill [11].

The Composition of student worksheet must be accord to feasible student worksheet requirement which reviewed by requirement of didactic, construction and technique. Student worksheet has a great influence in learning activity, so that composition of student worksheet have to fulfill requirement of didactic, construction and technique in order to applied into learning-teaching process [4]. Systematic of the presented subject and method on student worksheet 
coherently help them to relate the relation between subject and understanding the concept. This thing was supported by student's response result which explained that student worksheet can expand the subject insight and having no difficulty to understand. So that content of student worksheet according to learning goals, to ease for understands also validity of concept, principle and theory.

The effectiveness of student worksheet was reviewed by student's response. Student's response to carbohydrate metabolism student worksheet were positive up to $95.78 \%$ with very good category. They assumed that application of student worksheet based on inquiry can expand their insight and understand the subject of carbohydrate metabolism as well, Because of the students can identify the problems, formulate the sentences and hypothesis, to plan and do experiments, collect and analyze data, presents the result, and make conclusion [10].

\section{CONCLUSION}

Based on result conclude that validation result of carbohydrate metabolism student worksheet based on inquiry showed score 3.75 and feasible to applied. There was completeness of 2015 biology education student which showed value average 70.02 (B) for photosynthesis subject and 65.97 (B-) for respiration subject. Student's response against student worksheet were positive, up to $90.32 \%$ they assumed this carbohydrate metabolism student worksheet were effective toppled.

\section{REFERENCES}

[1] C. Schwarz, 'Developing Preservice Elementary Teachers' Knowledge and Practice Through Modeling Centered Scientific Inquiry,' Science Education, vol. 93, pp. 720-744, 2009.

[2] Pedaste, Margus, M. Maeors, A. Leijen and Sarapuu, "' Improving Students' Inquiry Skill through Reflection and Self-Regulation Scaffolds", Technology, Instruction, Cognition and Learning, vol. 9, pp. 81-95, 2012.

[3] L.M. Dweyer, 'The nature of science Instrument-Elementary (NOSI-E): The End of The Road," Journal of Applied Measurement, vol. 15, pp. 338-358, 2014.

[4] E. Widjajanti, Kualitas Lembar Kerja Siswa, Yogyakarta: UNY, 2008

[5] P. Andi, Panduan Kreatif Membuat Bahan Ajar Inovatif, Yogyakarta: Diva Press, 2013.

[6] Yuliani, S.R. Yuni S.R dan K.D. Sari, Penerapan Model Inkuiri pada Materi Metabolisme Karbohidrat untuk Meningkatkan Hasil Belajar dan Keterampilan Proses Mahasiswa Pendidikan Biologi 2015, Surabaya: LPPM Universitas Negeri Surabaya, 2017.

[7] M. Ibrahim, Asesmen Berkelanjutan, Konsep Dasar, Tahapan Pengembangan dan Contoh, Surabaya: Unesa University Press, 2015.

[8] Suparno, Filsafat Penelitian Kuantitatif Kualitatif dan R \& D, Bandung: Alfabeta, 2007.

[9] O. Bekiroğlu, Feral and A. Arslan, 'Examination of The Effects of Model-Based Inquiry on Students' Outcomes: Scientific Process Skills and Conceptual Knowledge', Procedia-Social and Behavioral, vol. 141, pp. 1187-1191, 2014.

[10] Pedaste, Margus, M. Mateots, L.A. Siiman, T.D. Jong, A.N. Siswa., V. Riesen, E.T. Kamp, C.M. Constantinos, C. Zacharia and E. Tsourliolaki, 'Phases of Inquiry-Based Learning: Definitions and The Inquiry Cycle’’ Educational Review, vol. 14, pp. 47-61, 2015.

[11] L. Che-Di, '’Worksheet Usage, Reading Achievement, Classes' Lack of Readiness, and Science Achievement: A Cross-County Comparison', International Journal of Education in Mathematics, Science and Technology, vol. 2, pp. 96-106, 2014. 